\title{
Descriptive Study of High Leprosy Endemic Pockets and Exploring Occurrence Factors of Multicase Families in the Village of Salaunikhurd of Chhattisgarh State
}

\author{
Sunil Gitte ${ }^{1, *}$, Latika Rewaria' ${ }^{1}$, V Santaram ${ }^{2}$, Sarosh Jamil ${ }^{3}$
}

\section{Sunil Gitte ${ }^{1, *}$, Latika Rewaria1, V Santaram², Sarosh Jamil ${ }^{3}$ \\ ${ }^{1}$ Central Leprosy Division, Directorate General of Health Services, Under Ministry of Health and Family Welfare, Govt of India, Delhi, INDIA. \\ ${ }^{2}$ Regional Leprosy Training and Research Institute, Under DGHS, MoHFW, Gol, Aska, Odisha, INDIA. ${ }^{3}$ World Health Organization (WHO) NTD Coordinator, Raipur, Chhattisgarh, INDIA.}

\section{Correspondence}

\section{Dr. Sunil Vilasrao Gitte}

Joint Director, Central Leprosy Division, Directorate General of Health Services, Under Ministry of Health and Family

Welfare, Delhi, INDIA.

Mobile no: +91-23910109

Email: sv.gitte@gov.in

\section{History}

- Submission Date: 01-01-2021;

- Revised Date: 27-01-2021

- Accepted Date: 15-03-2021;

DOI : 10.5530/ijmedph.2021.2.20

Article Available online

http://www.ijmedph.org/v11/i2

\section{Copyright}

(C) 2021 Phcog.Net. This is an openaccess article distributed under the terms of the Creative Commons Attribution 4.0 International license.

\begin{abstract}
Background: A notification received from state of Chhattisgarh in July, 2018 that 10 cases in a family of 14 members at Salaunikhurd village, Bhatgaon Primary Health Center (PHC), Block Bhilaigarh of Balodabazar district diagnosed as leprosy cases. In response, an investigation team was constituted by Central Leprosy Division to carry out the epidemiological investigation. Aim: To find out reasons of high leprosy endemicity, detailed investigation of multicase family and assessment of health service delivery in village. Methods: House to house survey of the village was carried out to find out new cases along with clinicepidemiological assessment of all patients affected with leprosy. Detailed investigation of two MCFs and assessment of health service delivery from block to the village level was carried out. Results: $84 \%$ of the village population screened for leprosy, two new leprosy cases, three defaulter and two newly developed Grade 2 Deformity (G2D) cases were identified during survey. All the cases in the Multi-case Family (MCF) were MB leprosy cases. Atypical signs and symptoms of leprosy - infiltrations and nodules over skin, low socio-economic status, poor housing condition, high family density, poor sanitation, seasonal migration, poor health seeking behaviour, lack of awareness on the disease and health system ignorance are the major factors led to delay in detection. Conclusion: Analysis of case detection trend in the region across the years indicates a smouldering epidemic of Leprosy. Multiple factors are responsible for the occurrence of multiple cases of leprosy within a family. Limitations: $100 \%$ population could not survey due to time constraint, harvesting season and migration. Molecular epidemiology study needed to explore the genetic structure which contributed MCF.

Key words: Multibacillary case (MB), Paucibacillary case (PB), Multi-case Family (MCF), Multi Drug Therapy (MDT), Under Treatment (UT), Release after Treatment (RFT).
\end{abstract}

\section{INTRODUCTION}

India has achieved the national target of leprosy elimination in Dec $2005^{1}$ but the state like Chhattisgarh and UT Dadra and Nagar Haveli yet to achieve the status of elimination. ${ }^{2}$ Chhattisgarh state has $2 \%$ of India's population and contributes about $9.31 \%$ of total leprosy cases in the country. ${ }^{3}$ Out of 27 districts, 24 districts are having $>10$ annual new case detection rate (ANCDR) in the year 2018-19. District Balodabazar is one of the 24 high endemic districts in the state. Familial and extra-familial close contacts play an important role in the epidemiology of childhood leprosy, occurrence of leprosy is most significant among leprosy infectious household's contacts. Positive contact history of leprosy has been shown to vary from $8.7 \%$ to $38.8 \% .^{4-6}$ Recent study revealed that infection with $M$. leprae is higher in close contacts sub clinically where their household members diagnosed as lepromatous and borderline lepromatous cases (high bacterial load).? At the household level, similarly other research has shown that proximity to and intensity of exposure to leprosy increases the risk of communication, as much as five to nine times that of non-household contacts, ${ }^{8-11}$ although leprosy clustering among neighbouring residences in areas of high population density and poverty has social contact risk similar to household contacts. ${ }^{12}$ Contact with a multibacillary case in the household has also been associated with increased risk of infection..$^{8,9,11,13}$ and indicates delay diagnosis and long-term exposure to contacts. Early detection of cases through regular surveillance and early access to the health care system would help to prevent and halt progressive deformity. The investigation carried out in the high endemic pocket of Balodabazar district to find leprosy cases in the village population, to ascertain the Clinicoepidemiological factors leading to Multi-Case Family (MCF) and to assess the service delivery of General Healthcare System in diagnosis, treatment and follow up of patients affected with leprosy.

\section{METHODS}

Settings: Study took place in village Salaunikhurd of Bilaigarh block of Chhattisgarh State, which 
geographically situated to the south of Mahanadi River, lying in close proximity with Janjgir Champa district. The village is divided into four clusters based on caste namely, Satnami, Kewat, Sahu and Yadav. There were 99 houses in the village with a enumerated population of 629.

\section{Study design and planning}

A cross-sectional descriptive study was designed to conduct houseto-house surveys from July 31 to August 1, 2018. Transect walk was undertaken to map the geographic area, nearby health facilities, spread of households in village, a local village map was prepared with the help of head of the village. A rendezvous location was identified in the village for coordination of survey activities by the investigation team. Seven teams (consisting of 1 male and 1 female member) were made, headed by a supervisor (Non-Medical Supervisor/ Investigators) to conduct the screening survey. Teams were briefed about the house-to-house survey techniques and predesigned proforma filling. All available residing individuals were screened clinically by proper visualization of body parts in day light after obtaining verbal consent, and privacy of female members was taken into consideration.

\section{Data Collection and tools used}

Geographical coordinates (latitude and longitude) of households of persons affected with leprosy were recorded using a Google Map coordinate. Standard tool for screening leprosy used as mentioned in Leprosy Case Detection Campaign (LCDC) operational guidelines. ${ }^{14}$ National Leprosy Eradication Program services and patient records maintained at Block, PHC and Sub Centre was also reviewed along with interaction with health functionaries like ASHAs, Non-Medical Assistants, Auxiliary Nurse and Midwifery, Block Medical Officer, District and State Leprosy Officers.

\section{Survey}

House to house leprosy screening survey of whole village was conducted by seven teams. Houses marked as "L" house, where all members available and screened for leprosy and the houses marked as " $\mathrm{X}$ " house, where all members were not available during survey visit. Demographic and clinical information as per screening tool were recorded in predesigned proforma. Follow-up visits were made on $2^{\text {nd }}$ day to cover the missing members of " $X$ " houses. All suspected cases were listed and clinically examined by the investigators as per standard GoI guidelines. Confirmed cases were categorized and put on Multi Drug Therapy as per standard guidelines.

During survey, two Multi Case families (MCF) were identified for detailed investigation, and their information was recorded in separate specially designed proforma which included details of family composition, literacy, occupation, income, nutritional status, basal metabolic index (BMI), reasons for a delay in seeking health care, health-seeking behaviour, migration, housing and sanitation practices. Detailed clinical examination for leprosy also carried out for each member of MCF by using standard operational definitions of Government of India ${ }^{14-16}$

\section{RESULTS}

Patient case records of last 4 years revealed there were total 24 cases detected in the studied population. Table 1 depicts that population and household coverage during the survey, 16 out of total surveyed houses reported 99 people migrated from village. Major NLEP programmatic indicators like ANCRD, G2D cases and prevalence rate are significantly increased from 2015 to 2018 in the Bhilaigarh Block of Chhattisgarh as shown in Graph 1, clearly shows the Bilaigarh Block is endemic for leprosy and indicative of hidden cases in the community. Occurrence of G2D cases in the Bhilaigarh block from 2015-2017 was also studied, out of 215 villages, 34 (15.8\%) villages reported single case of G2D and $8(3.7 \%)$ villages reported more than one case of G2D detected in those 2 years, High percentage of G2D cases is evident in leprosy endemic pockets. Figure 1 shows the village wise distribution of G2D cases and geo location of Public health facilities in Bhilaigarh block. Block has 7 PHC and 39 SC uniformly located, Salaunikhurd village is easily approachable to nearby Sub-health centre Salaunikala and PHC Bhatgaon and far from Bilaigarh CHC.

Household geographic coordinates of all leprosy affected people recorded, Spatial distribution (Geo-coordinates) is shown in Figure 2, GPS mapping reveals that distribution of cases is across the locality in all directions, a cluster of cases was significantly marked in Kewat Para and adjoining lane (17 cases).

\section{Age and sex distribution}

$50 \%$ of the village population was in reproductive age group (15 to 44 years), $29 \%$ were children ( $<14$ Years), and 10\% were above the age of 60 years. $29 \%$ of the population were illiterate and the majority of the population (49\%) engaged in agriculture work seasonally followed by non-agricultural labour (10\%).

Profile of suspected and new cases- Six suspects ( 4 females and 2 males) were identified and clinically examined by the investigators. All suspects had a single patch on the visible parts (hands, abdomen and back) of the body. Out of six suspects, four had a common skin infection and two were confirmed cases of leprosy (1-MB, 1-PB).

Profile of Release from Treatment (RFT) and Under Treatment (UT) cases- 16 RFT/Old cases and 5 UT cases were also examined. Team found

Table 1: Population, house coverage and new case detection in Salaunikhurd village, Bhilaigarh Block (July 31 and August 1 2018).

\begin{tabular}{|c|c|c|c|c|c|c|c|c|c|}
\hline Sr No & $\begin{array}{l}\text { Survey } \\
\text { Team }\end{array}$ & $\begin{array}{c}\text { No of } \\
\text { Houses } \\
\text { Covered }\end{array}$ & $X$ houses & $\begin{array}{c}\text { Total } \\
\text { population }\end{array}$ & $\begin{array}{l}\text { Covered } \\
\text { population }\end{array}$ & Suspect & $\begin{array}{l}\text { Confirmed as } \\
\text { new case }\end{array}$ & $\begin{array}{c}\text { Old } \\
\text { (RFT) }\end{array}$ & UT \\
\hline 1 & Team-1 & 23 & 7 & 161 & 143 & 00 & 00 & 10 & 00 \\
\hline 2 & Team-2 & 17 & 0 & 115 & 88 & 02 & 00 & 02 & 00 \\
\hline 3 & Team-3 & 10 & 3 & 59 & 56 & 00 & 00 & 01 & 00 \\
\hline 4 & Team-4 & 11 & 3 & 85 & 77 & 00 & 00 & 00 & 02 \\
\hline 5 & Team-5 & 10 & 0 & 63 & 38 & 00 & 00 & 01 & 00 \\
\hline 6 & Team-6 & 17 & 0 & 92 & 77 & 03 & $1(\mathrm{~PB})$ & 00 & 00 \\
\hline 7 & Team-7 & 7 & 3 & 54 & 51 & 01 & $1(\mathrm{MB})$ & 02 & 03 \\
\hline Total & & 95 & 16 & 629 & 530 & 06 & 02 & 16 & 05 \\
\hline
\end{tabular}


three defaulter cases, all were active MB cases (infiltration, nodules over earlobes and body, depressed nasal bridge and supraciliary madarosis), one with Erythema Nodusum Leprosum (ENL) reaction and one with recent left foot drop. All 3 defaulters were categorized as 'Other Case' and restarted MDT as per schedule. Out of three defaulters, one had recent foot drop ( $<2$ months) was put on a standard dose of steroid and physiotherapy.

Disability status of patients: Only one patient had G2D at the time of diagnosis, but during an interview and clinical examination, two more G2D cases were detected (1 foot drop, 1 claw foot) also summarized at Table 1. No child deformity was found.

Factious factors like family composition, clinical presentation, Socioeconomic status, migratory patterns, delays in detection, health seeking behavior and other factors contributed to Multi-case families and delay in case detection are depicted in Table 2.

Assessment of NLEP and Public Health services in the village: Village is easily accessible to sub-health center- Salaunikala and PHCBhatgaon, but majority of UT cases were seeking anti-leprosy services from Community Health Center (CHC)- Bilaigarh $35 \mathrm{~km}$ away from the village. PHC and SC found non-functional towards NLEP services as NLEP services were directly administered and controlled by Bilaigarh Block. Mini vertical setup in the integration of NLEP with general health system is existing at Bilaigarh block. The involvement of Health staff of Sub centre and Primary Health Centre during routine case detection

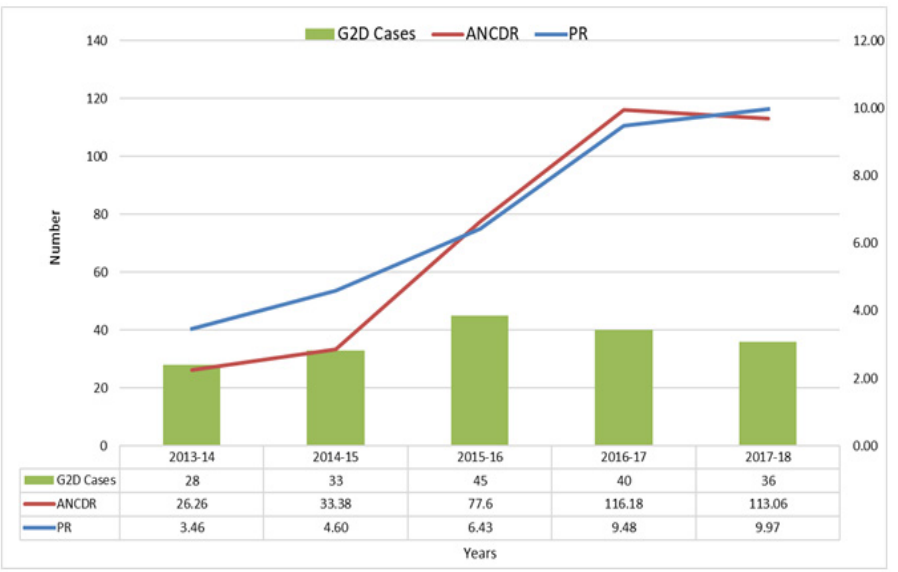

Graph 1: Shows epidemiological indicators of Bhilaigarh block.

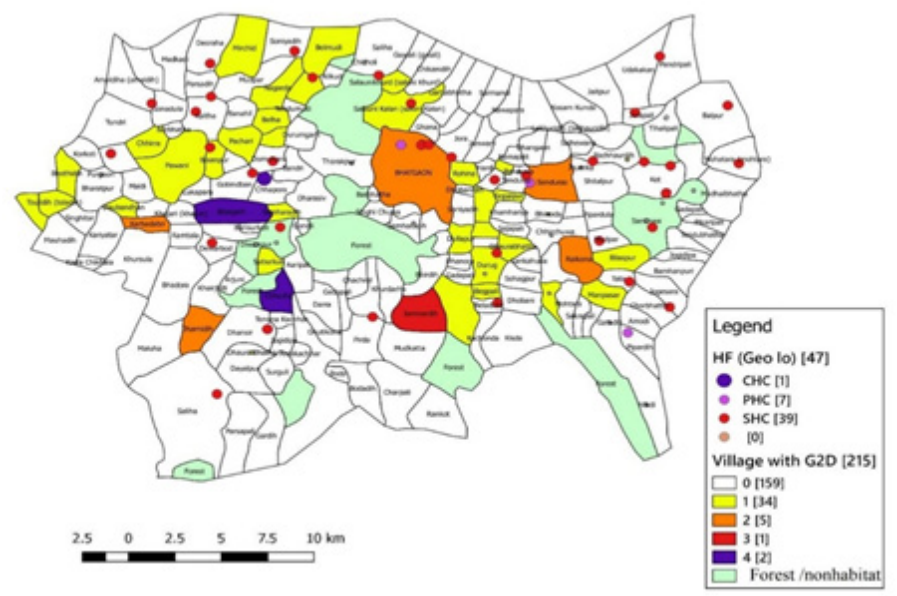

Figure 1: Habitat wise mapping of Grade 2 disabilities and location of Public health facilities in Bhilaigarh block -Year. campaigns were sub optimal lacking in coverage, supervision and data review. Data mismatch was found in the patient records of the Health facility indicating gaps in the surveillance. Patient record registers were not filled completely and follow up investigations like Voluntary Muscle Test and Sensory Test (VMT ST) were not performed and recorded, no G2D investigation record was available, incomplete UT patient's follow-up registers, delayed and duplicate entries for MDT dispensed, 2 cases were wrongly marked as RFT as they were found to be on MDT continuing treatment. 3 cases were found who have discontinued treatment for more than 6 months and no mention of this was found in health records.

\section{DISCUSSION}

Balodabazar has a significant increase in detection of new leprosy cases after its formation in 2013 and district identified as high endemic in 2016 due to few endemic villages, including Salaunikhurd village. There has been minimal involvement of GHS in implementing routine NLEP services; It could be due to the conceptual thinking considering NLEP is still a vertically implemented program by only the vertical staff i.e. NMA/NMS at district. Infact, there has been irrational deployment of vertical staff as far as the endemicity is concerned. The block was part of Raipur district till 2013, after this new district Balodabazar formed. Block was administratively far from district HQ of Raipur thereby NLEP activities could have been compromised before 2013. ANCDR of the block was between 35- 26 per lakh population till 2013. After formation of a new district, the block came under near administrative control and implementation of NLEP activities stepped up. ANCDR trend started increasing exponentially from 2014, Bilaigarh block has continued transmission of leprosy, a sharp rise in case detection can be attributed to increase in number of active case search campaigns with focus by the newly formed district. The health department also took initiative in expanding the outreach of campaigns, these efforts led to fivefold increase in cases in the last 4 years. This indicated detection of hidden and backlog cases in the population. In spite of these campaigns, the district lacked in ensuring quality of case detection, supervision and follow up activities, which led to the multicase family.

Performance of case detection activities reflects the performance of leprosy control program, in spite of previous active searches in the village before Sep 2016, nineteen cases were later detected were missed during previous campaigns. Ten cases in the family reported in a short span of three months, indicating transmission and suffering after being missed in the previous campaigns. Along with this, another family with two cases was also missed in the previous campaign. This reveals poor quality of LCDC campaign and lack of involvement of ASHAs. LCDC, which was a time-bound activity, created a basic platform for leprosy detection activities at ground level with the multisectoral participation and built

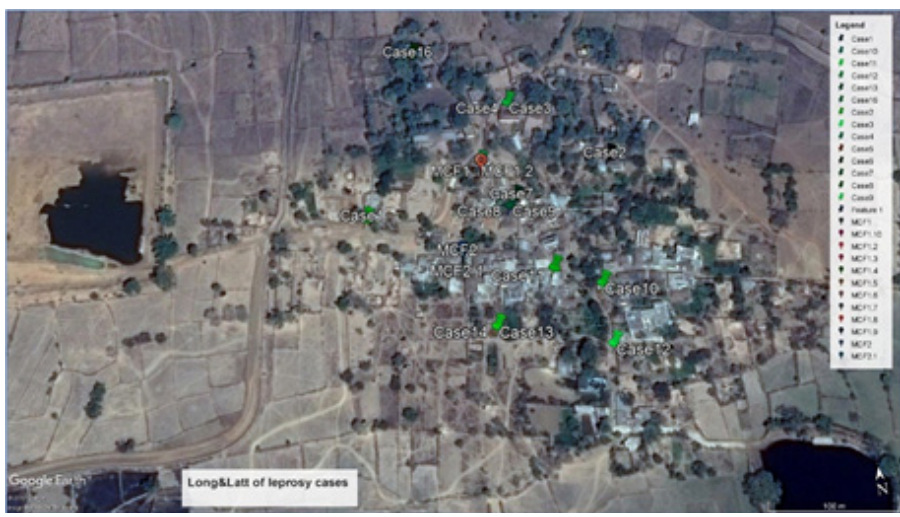

Figure 2: Geo Coordinate of leprosy cases at Salaunikhurd village. 
Table 2: details of family composition, clinical presentation, socio-economic status, delays, health seeking behaviour and other factors of multicase families.

\begin{tabular}{|c|c|c|}
\hline Variables & MCF 1 & MCF 2 \\
\hline $\begin{array}{l}\text { Family } \\
\text { structure }\end{array}$ & Nuclear, one couple 8 children & Joint family, Mother, three son (two married) \\
\hline Occupation & $\begin{array}{l}\text { Father -skilled construction worker, Mother, agriculture/daily wage labor. } \\
\text { All children work as daily wage laborers except one son who is a student. }\end{array}$ & $\begin{array}{l}\text { The family works as daily wage laborer and engaged in } \\
\text { agricultural activities. Eldest son is married and have } 5 \text { children. }\end{array}$ \\
\hline $\begin{array}{l}\text { MCF, } \\
\text { confirmed } \\
\text { cases }\end{array}$ & $\begin{array}{l}10 \text { cases, all are MB cases, Extended family member's on-in-law and the } \\
\text { grandson (6years) are also confirmed MB case of leprosy. Total } 12 \text { cases. }\end{array}$ & Two MB cases \\
\hline $\begin{array}{l}\text { Socio- } \\
\text { economic } \\
\text { status }\end{array}$ & $\begin{array}{l}\text { Mother and father, both are illiterate, remaining members are having basic } \\
\text { education. Family does not have fixed source of income and depends on } \\
\text { availability of work, preferably outside state. Computing the daily wage of } \\
\text { individual members, duration of work and distributing it among all family } \\
\text { members, the annual per capita income came as INR1000 only. }\end{array}$ & $\begin{array}{l}\text { Family does not have any fixed source of income and depends on } \\
\text { availability of work, preferably outside state. The annual per capita } \\
\text { income is less than INR } 1000 \text { per family member. }\end{array}$ \\
\hline $\begin{array}{l}\text { Decision } \\
\text { Maker }\end{array}$ & Father & Son \\
\hline Migration & $\begin{array}{l}\text { Family migrates for work in batches; take turns to stay in the village while } \\
\text { the other group migrates within or outside state. }\end{array}$ & Eldest son migrates for $4-5$ months in the year. \\
\hline $\begin{array}{c}\text { Clinical } \\
\text { presentation }\end{array}$ & $\begin{array}{l}\text { Infiltrations and ear nodules recorded at the time of diagnosis in six } \\
\text { members }\end{array}$ & $\begin{array}{l}\text { The elder brother had infiltration lesions over the face and patches } \\
\text { in the arm. Younger brother has only infiltration over nose, ears } \\
\text { and face. }\end{array}$ \\
\hline $\begin{array}{l}\text { Health seeking } \\
\text { preferences }\end{array}$ & $\begin{array}{l}\text { Local quacks/ unqualified medical practitioner for general and non-serious } \\
\text { illness. }\end{array}$ & $\begin{array}{l}\text { Tried treatment from 'Jharphook wala' and Faith-healer in the } \\
\text { nearby village. And private practitioner }\end{array}$ \\
\hline $\begin{array}{c}\text { Cause of } \\
\text { patient related } \\
\text { delay }\end{array}$ & $\begin{array}{l}\text { The symptoms were not worrisome, and the patient hoped that it will } \\
\text { be cured on its own. The contact with private health care was minimal } \\
\text { because of the poor economic status of the family. The migratory nature } \\
\text { of the family also delayed in seeking health care as the decision maker } \\
\text { was not usually present with the family at all time. Lack of information } \\
\text { about the health provider in the place where they migrated for work also } \\
\text { contributed to the delay. It was not clearly indicated but there can be fear of } \\
\text { stigma and discrimination by the villagers }\end{array}$ & $\begin{array}{l}\text { Symptoms were not worrisome, and the patient hoped that it will } \\
\text { be cured on its own. Lack of awareness about the disease among } \\
\text { the family members. Faith healer is relative of the family so } \\
\text { eminent trust on him led to delay in contact with the public health } \\
\text { system. Local private practitioner unable to detect and refer the } \\
\text { case to the public health system. }\end{array}$ \\
\hline $\begin{array}{l}\text { Causes of } \\
\text { Health system } \\
\text { delay }\end{array}$ & $\begin{array}{l}\text { Suboptimal involvement of Mitanin (ASHA) of the village. The subsequent } \\
\text { case detection campaigns implemented by Mitanin failed to detect suspects } \\
\text { of leprosy in the village. There was lack of involvement of PHC and health } \\
\text { subcenter in detection, diagnosis, record keeping, treatment and follow-up } \\
\text { of the cases. This indicates reduced engagement and capacity of general } \\
\text { health system in leprosy control. The subsequent case detection campaigns } \\
\text { implemented failed to detect suspects of leprosy in the village }\end{array}$ & \\
\hline
\end{tabular}

rapport at the village level. There was a need to utilize and sustain the leprosy activity at the village level by the involvement of PRI members in coordination with health staff. The efforts or IEC activities needed to be reinforced at the village level and be regularly repeated, again and time for making a successful and sustained effect. As detection of so many cases show the possibility of many more hidden cases in the community, which can only be detected and brought for treatment through effective and sustained IEC activities.Clustering of cases in the village and among close family contacts indicates the local risk of spreading the disease. The proliferation of leprosy in the village continues largely in conditions of poverty that includes poor housing, sanitation, high household density, illiteracy, low socio-economic status and low awareness about the disease. Nevertheless, household leprosy contact continues to be the primary risk factor associated with leprosy infection. Since 2016$17,65 \%$ of cases were MB in the village. They are all epidemiologically important cases as far as transmission is concerned. The patient suffering from MB leprosy requires extra care and support from General Health Service GHS as they are at risk of developing reaction, deformity and disability. Clinical features of some $\mathrm{MB}$ cases having nodules and infiltration over the ears, supraciliary madarosis and depressed nasal bridge indicative of Lepromatous Leprosy cases and they are a major source of transmission. Close contacts of leprosy patients are known to have high risk of getting leprosy, given that leprosy is spread from person to person mainly through droplets. The extent of the risk is dependent on the closeness of contact; household contacts (those living in the same house and sharing the same facilities) appear to have the highest risk. It is already known that there is a 4-fold risk of developing leprosy in the presence of a neighborhood contact, and this risk increases to 9 fold if there is a household contact. ${ }^{8,17}$ There are chances of occurrence of leprosy in household contacts with the degree of intimacy. The importance of intimacy was also brought out by the higher attack rate for a child when their mother are the index case as compared with the 
situation when father are index case, the assumption being that children are closer to mother than their father. Bed contacts are also important, and it increases the chance of getting leprosy within the family. Among familial contacts, the risk of infection increases from 35\% to $65 \%$ if the index case is suffering from multibacillary (MB) leprosy as compared to paucibacillary (PB) leprosy. Genetic predisposition to susceptibility regarding the spectrum of disease cannot be ruled out and is a subject beyond the scope of this investigation.

Seasonal migrations of the multi-case families along with the socioeconomic variables leads to delay in decision making and are highly likely to seek treatment from unqualified practitioners resulting in morbidity. This population is at high risk of getting disability, deformity and defaulting treatment. This investigation brings out that the main reason of delay in diagnosis of Leprosy patients is because they have not reached to the right place at the right time due to migration, illiteracy, lack of awareness, poor health-seeking behavior and low socio-economic status. Delay in detection, poor follow-up of patients, and poor tracking of defaulter's causes continued transmission and spread of the disease.

Leprosy being the disease of the long incubation period, sustained activities at all level will lead to early case detection through regular surveillance, less grade 2 disabilities, reduce stigma, and ultimately break transmission chain at community level. Many such endemic pockets may be there in high as well as low endemic states require these sorts of interventions like active case detection and regular surveillance.

\section{Limitations}

Due to time constraint, plantation season and migratory nature of the villagers, the team could not survey $100 \%$ population. Detailed epidemiological investigation of the index case of the MCF could not be carried out due to migration of the members. Further, molecular epidemiology study needed to explore the family genetic structure which contributed to multiple leprosy cases in the family.

\section{CONCLUSION}

Case detection in the block across the years indicates smoldering epidemic of leprosy and large number of cases detected in the village indicates continued silent community transmission. There was a bilateral delay (Patient driven, and Health System driven) in case detection led to multi-case family in the studied population. The gaps in program implementation of NLEP led to lack of data analysis at the block level and could not detect the clustering of cases. In the endemic area, the migratory population of low socio-economic status is at risk of getting leprosy and lead to delay in diagnosis, interruption of treatment and risk of developing disability and complications. The Information Education Communication campaign should be carried with missionary zeal so that more and more people affected by leprosy come forward for treatment.

\section{ACKNOWLEDGEMENT}

Authors acknowledge the support of Dr. Anil Kumar, DDG-LeprosyDGHS and Dr. Aparna Pandey, Director-RLTRI, Raipur. Also thankful to the Chhattisgarh state NLEP staff - Dr M Deshpande (SLO, Chhattisgarh), Dr Kurrey (SMO, Chhattisgarh), Dr Nirala (DLO, Balodabazar), Dr Rakesh Kumar (District Leprosy Consultant) and Non-Medical Assistant, Salaunikhurd Village for providing all necessary logistic and mobilization support to conduct the investigation smoothly. Special thanks to all the community members for participating in the study.

\section{CONFLICT OF INTEREST}

The authors declare that there is no conflict of interest.

\section{ABBREVIATIONS}

ANCDR: Annual New Case Detection Rate; AMO: Assistant Medical Officer; ANM: Auxillary Nurse Midwifre; ASHA: Accredited social health Activist; BCP: Blister pack; CHC: Community Health Center; DPMR: Disability Prevention and Medical Rehabilitation; EHF: Eye Hand and Feet; FGDs: Focus Group Discussion; FLC: Focus Leprosy Campagin; GHS: General Health Care system; G2D: Grade 2 disability; LCDC: Leprosy case detection Camagin; MB type: Multibacillary leprosy; MDT: Multidrug Treatment; MPW: Multipurpose Worker; MCF: Multicase Family; MTs: Mitanins Trainers; NLEP: National Leprosy Eradication Programme; NMAs: Non Medical Assistants; PB Case: Paucibacillary Leprosy; PHC: Primary Health care center; RFT: Released after treatment; IEC: Information education and communication; PR: Prevalence Rate; PAL: Patient affected with Leprosy.

\section{REFERENCES}

1. Singal A, Sonthalia S. Leprosy in post-elimination era in India: Difficult journey ahead. Indian Journal of Dermatology. 2013;58(6):443-6.

2. Rao PN, Suneetha S. Current Situation of Leprosy in India and its Future Implications. Indian Dermatol Online J. 2018;9(2):83-9.

3. National Leprosy Eradication Programme. Current leprosy situation in India. Directorate General of Health Services, Ministry of Health and Family Welfare Government of India, New Delhi; 2006. Available from: http://www.nlep.nic. in/data2.html.

4. Mahajan S, Sardana K, Bhushan P, Koranne RV, Mendiratta V. A study of leprosy in children, from a tertiary pediatric hospital in India. Lepr Rev. 2006;77(20):1602 .

5. Shetty VP, Ghate SD, Wakade AV, Thakar UH, Thakur DV, D'souza E. Clinical, bacteriological, and histopathological characteristics of newly detected children with leprosy: A population based study in a defined rural and urban area of $\mathrm{Ma}-$ harashtra, Western India. Indian J Dermatol Venereol Leprol. 2013;79(4):512-7.

6. Rao AG. Study of leprosy in children. Indian J Lepr. 2009;81(4):195-7.

7. Das M, Diana D, Wedderburn A, Rajan L, Rao S, Horo I, et al. Molecular epidemiology and transmission dynamics of leprosy among multicase families and case-contact pairs. International Journal of Infectious Diseases. 2020;96:172-9.

8. Sales AM, Leon AP, Duppre NC, Hacker MA, Nery JA, et al. Leprosy among patient contacts: A multilevel study of risk factors. PLoS NTD. 2011;5(3):e1013.

9. Moet F, Pahan D, Schuring R, Oskam L, Richardus J. Physical distance, genetic relationship, age and leprosy classification are independent risk factors for leprosy in contacts of patients with leprosy. J of Infec Dis. 2006;193(3):346-53.

10. Durães SM, Guedes LS, Cunha MD, Magnanini MM, Oliveira ML. Epidemiologic study of 107 cases of families with leprosy in Duque deCaxias, Rio de Janeiro, Brazil. An Bras Dermatol. 2010;85(3):339-45

11. Van Beers $S$, Hatta M, Klatser P. Patient contact is the major determinant in incident leprosy: Implications for future control. Int J Lepr Other Mycobact Dis. 1999;67(2):119-28.

12. Moura MLN, Dupnik KM, Sampaio GAA, Nóbrega PFC, Jeronimo AK, et al. Active Surveillance of Hansen's Disease (Leprosy): Importance for Case Finding among Extra-domiciliary Contacts. PLoS Negl Trop Dis. 2013;7(3):e2093.

13. Fine P, Sterne J, Ponninghaus J, Bliss L, Saul J, et al. Household and dwelling contact as risk factors for leprosy in Northern Malawi. Am J Epidemiol. 1997; 146(1):91-102.

14. National Leprosy Elimination Programme: Operational Guideline for LCDC 2020. Cited Sept 152020 http://cghealth.nic.in/ehealth/2016/Instructions/Draft_ OperationalGuidelines_LCDC.doc

15. National Leprosy Elimination Programme: Training manual for Medical officer 2019. Cited Sept 15 2020.https://cltri.gov.in/MO\%20Training\%20Manual.pdf,

16. Chokkakula S, Attitalla IH, Male MM, et al. Molecular Typing of Mycobacterium leprae by Variable Number Tandem Repeats in Multicase Families of Leprosy. EC Microbiology. 2016;3:511-8.

17. MuthuvelT, Govindarajulu S, Isaakidis P, Shewade HD, Rokade V, Singh R, et al "I Wasted 3 Years, Thinking It's Not a Problem": Patient and Health System Delays in Diagnosis of Leprosy in India: A Mixed-Methods Study. PLoS Negl Trop Dis. 2017;11(1):e0005192. https://doi.org/10.1371/journal.pntd.0005192 